\title{
Determination of the Toxicological Risk of Urban Waste from the City of Uvira Dumped into the North-Western Coast in Lake Tanganyika (Democratic Republic of Congo)
}

\author{
Lumami Kapepula Vercus $1,2,3,4^{*}$, Théophile Ndikumana ${ }^{2,3}$, Njoyim Estella Buleng Tamungang5,6 (1), \\ Musibono Dieu-Donné7, Lukusa Mbaya Alain ${ }^{7}$, Nsimanda Ipey Camille ${ }^{7}$, Patricia Luis Alconero ${ }^{4,8}$, \\ Bart Van Der Bruggen9,10
}

${ }^{1}$ Department of Hydrology, Hydrobiology Research Center, Uvira, R.D. Congo

${ }^{2}$ Department of Chemistry, University of Burundi, Bujumbura, Burundi

${ }^{3}$ Doctoral School of the University of Burundi, Bujumbura, Burundi

${ }^{4}$ Materials \& Process Engineering (IMAP), Catholic University of Louvain, Place Sainte Barbe 2, B-1348 Louvain-la-Neuve, Belgium

${ }^{5}$ Department of Chemistry, Faculty of Science, University of Dschang, Dschang, Cameroon

${ }^{6}$ Department of Chemistry, Higher Teacher Training College, The University of Bamenda, Bamenda, Cameroon

${ }^{7}$ Department of the Environment, University of Kinshasa, Kinshasa, D.R. Congo

${ }^{8}$ Research \& Innovation Center for Process Engineering (ReCIPE), Place Sainte Barbe 2, bte L5.02.02, B-1348 Louvain-la-Neuve, Belgium

${ }^{9}$ Process Engineering for Sustainable Systems (ProcESS), Katholieke Universiteit Leuven, Celestijnenlaan 200f, 3001 Leuven, Belgium

${ }^{10}$ Faculty of Engineering and the Built Environment, Tshwane University of Technology, Pretoria, South Africa

Email: ^lumamikapepula@gmail.com

How to cite this paper: Vercus, L.K., Ndikumana, T., Tamungang, N.E.B., DieuDonné, M., Alain, L.M., Camille, N.I., Alconero, P.L. and Van Der Bruggen, B. (2021) Determination of the Toxicological Risk of Urban Waste from the City of Uvira Dumped into the North-Western Coast in Lake Tanganyika (Democratic Republic of Congo). Journal of Environmental Protection, 12, 677-693.

https://doi.org/10.4236/jep.2021.1210041

Received: August 19, 2021

Accepted: October 12, 2021

Published: October 15, 2021

\begin{abstract}
This study focuses on determining the toxicological risks of urban waste from the city of Uvira, discharged into Lake Tanganyika, on the surrounding population. Volatile organic compounds were measured in a variety of solid waste matrices, including inorganic micropollutants in wastewater and fish. The concentrations of $\mathrm{Hg}$ and $\mathrm{Pb}$ in the lake were found to be 1.21 and $1.42 \mu \mathrm{g} / \mathrm{L}$ respectively and between 0.83 to $18.36 \mu \mathrm{g} / \mathrm{L}$ of $\mathrm{Hg}$ and 8.25 to $670 \mu \mathrm{g} / \mathrm{L} \mathrm{of} \mathrm{Pb}$, at the collector outlet. The presence of trace metallic elements, such as $\mathrm{Cr}, \mathrm{Co}$, $\mathrm{Ni}, \mathrm{Cu}, \mathrm{Zn}, \mathrm{As}, \mathrm{Sb}, \mathrm{Hg}$ and $\mathrm{Pb}$, were detected at high concentrations compared to the WHO standard. An ecotoxicology experiment herein on wastewater samples showed lethal pollutant concentrations of the order of 0.0055 $\mathrm{mL} / \mathrm{mL}$ which killed at least $50 \%$ of fish (LC50), confirming the toxicity of the wastewater. These potentially harmful effluents also contain volatile organic compounds originating in high concentration from the pharmaceutical discharges of the general Uvira hospital, in particular: toluene, ethylbenzene, $\mathrm{m}$ xylene/p-xylene, o-xylene and chloroform in higher concentrations compared
\end{abstract}


Copyright (c) 2021 by author(s) and Scientific Research Publishing Inc. This work is licensed under the Creative Commons Attribution International License (CC BY 4.0).

http://creativecommons.org/licenses/by/4.0/ to the norm. Other components such as benzene, bromodichloroethane and 1,1-dichloroethane were found to be present, but at a concentration below $0.05 \mathrm{ppb}$. A variety of trace organics can be suspected to be present as well.

\section{Keywords}

Lake Tanganyika, Lethal Dose, Volatile Organic Compounds, Heavy Metals, Water Pollution

\section{Introduction}

The hydrosphere is among the ecosystems most threatened by the impact of anthropogenic effects over the past century [1] [2] [3]. Living things can be exposed to a large number of xenobiotics, synthetic or natural (toxins), from microorganisms, plants or animals, which can disrupt the normal metabolic processes of a person or animal and thus are harmful to the body. These can be toxic products, such as environmental pollutants (metals, pesticides and plant protection products, polychlorinated hydrocarbons and non-medicinal narcotics [4]. More recently, micropollutants are linked to diffuse emissions of particles and domestic practices [5]. Among the most commonly encountered organic micropollutants are 1,4-dichlorobenzene, 1,1-dichloroethane, toluene, xylenes, ethylenediaminetetraacetic acid EDTA and acetone [6]. In addition, there are also pharmaceuticals and stimulants such as caffeine, salicylic acid and diclofenac. It is interesting to note that the low concentration of trace organic compounds in wastewater and their low biodegradability make their treatment difficult in intensive purification processes [7].

Heavy metal pollution has become a concern because industrial wastewater containing copper, cadmium, zinc, lead, mercury and manganese etc. are often deliberately or accidentally released into local water resources [8]. The treatment of heavy metals is of particular concern because of their resistant nature and their persistence in the environment [9] [10] [11].

Unlike organic contaminants, heavy metals tend to accumulate in living organisms and many heavy metals are known to be toxic or carcinogenic like Cadmium $(\mathrm{Cd})$, mercury $(\mathrm{Hg})$ and lead $(\mathrm{Pb})[12]$ [13]. Toxic heavy metals present special concerns in industrial wastewater treatment containing zinc, copper, nickel, mercury, cadmium, lead and chromium [10]. They are transferred through the aquatic environment to fish, humans and other piscivorous animals and can have negative impacts on the environment and human health [14]. Thus, aquatic life may be exposed to high concentrations of heavy metals and trace metals depending on their bioavailability and the particular organism exposed and may become persistent in the environment and constitute a degradation challenge aggravated by the lack of available data [15] [16] [17]. The problems associated with heavy metal contamination were first highlighted in industrialized countries, due to 
their larger industrial developments, and especially following accidents due to cadmium pollution in Sweden, and mercury in Japan (Minamata disease from 1949 to 1965) [18] [19].

The level of industrial activities is lower in most African countries, with 19\% in North Africa and $14 \%$ in Sub-Saharan Africa, thus allowing activities to be monitored. This contributes to increased productivity, reduction of waste and emissions, and management of energy consumption [20]. There is growing awareness of the need to rationally manage aquatic resources and in particular to control waste discharges into the environment [21] [22] [23] [24].

In Africa, population growth, rural exodus and the degradation of the environment constitute great threats which weigh on humanity. Indeed, the growing population is increasingly concentrated in the cities. All of the foregoing can dangerously affect aquatic ecosystems and pose a long-term danger to human existence.

The demography of the Democratic Republic of Congo (DRC) is high hence poor soil occupation due to anarchic constructions mainly situated at the base of erosions. Moreover, the technique locally used to fight against these erosions is the installation of bins to retain the soil which goes a long way to explain the abundance of waste in the Democratic Republic of Congo. This calls for urban waste management as a major concern for the preservation of the environment [25] [26]. The city of Uvira, located in the province of South Kivu in the east of the Democratic Republic of Congo and in the North-west of Lake Tanganyika, is encountering a critical pollution problem due to lack of a sewer network, as well as a liquid and solid waste treatment plant. Consequently, all of the household waste, both solid and liquid, is dumped in the gutters of several avenues of the municipalities from where they are carried to Lake Tanganyika [26].

This is the case of the large collector built by the Belgian Technical Cooperation, which carries hospital effluents from the Uvira General Reference Hospital and effluents from the central prison of Uvira to Lake Tanganyika.

Meanwhile, the population obtains water for domestic use from the shore of Lake Tanganyika, fishing is done near the coast between 0 and 5 meters deep [27]. It is therefore possible that the population is infected with water-borne diseases due to the contamination of coastal waters. The various annual reports of the health zone of Uvira in the Democratic Republic of Congo have established cases of water-borne diseases in the city from 2014-2019 as shown in Table 1 below.

The main aim of this work was to determine the toxicity caused by waste discharged into Lake Tanganyika, due to lack of proper sanitation, and the negative impacts of this situation of the inhabitants of Uvira. In a previous study [28], the threat of physico-chemical pollution on the lake coast was studied. The present work is geared towards the development of a master plan for the management of liquid and solid effluents in the countries bordering Lake Tanganyika as well as everywhere else, and to develop strategies for the elimination of wastewater pollutants. 
Table 1. Annual statistics of water-borne diseases and disseminated by water-related vectors (HGR Uvira).

\begin{tabular}{|c|c|c|c|c|c|c|c|c|c|c|c|c|}
\hline \multirow[b]{2}{*}{ Disease } & \multicolumn{2}{|c|}{2014} & \multicolumn{2}{|c|}{2015} & \multicolumn{2}{|c|}{2016} & \multicolumn{2}{|c|}{2017} & \multicolumn{2}{|c|}{2018} & \multicolumn{2}{|c|}{2019} \\
\hline & Case & Death & Case & Death & Case & Death & Case & Death & Case & Death & Case & Death \\
\hline Cholera & 1914 & 9 & 1364 & 7 & 1434 & 9 & 1266 & 6 & 1078 & 9 & 959 & 11 \\
\hline Typhoid & 15,128 & 46 & 18,994 & 36 & 22,415 & 2 & 18,582 & 8 & 17,896 & & & \\
\hline Diarrhea & 1474 & 14 & 11,500 & 10 & 13,318 & 3 & 14,847 & 7 & 11,783 & & & \\
\hline Malaria & 46,184 & 175 & 59,475 & 64 & 69,216 & 16 & 72,915 & 58 & 50,005 & & & \\
\hline Hepatitis & 8 & 0 & 41 & 3 & 15 & 2 & 50 & 2 & 86 & & 44 & \\
\hline Histosomiasis & 6 & 0 & 6 & 0 & 49 & 1 & 29 & 2 & 114 & & & \\
\hline
\end{tabular}

Annual reports from the Uvira/South Kivu health zone in the Democratic Republic of Congo.

\section{Materials and Methods}

\subsection{Presentation of the Study Environment}

Figure 1 shows the study area, as located by Google Earth and the Arc GIS version 9.3 software. The GPS enabled the geographic coordinates of the sampling sites to be determined. Wastewater was collected at point S4 with coordinates $029^{\circ} 08^{\prime} 39.0^{\prime \prime}$ longitude $\mathrm{N}$ and $03^{\circ} 24^{\prime} 26.3^{\prime \prime}$ latitude $\mathrm{E}$ and was taken to the aquarium room of the Hydrobiology research Center for experiments.

Figure 1 shows the sites of fish capture in blue and green colors. This study was mainly centered around these sites. The site in yellow color shows the facility in which water samples from Lake Tanganyika were diluted in aquariums in order to determine the pollutant doses therein

From a geological point of view, the slope of the western edge of the graben of Lake Tanganyika is represented by a metamorphosed Precambrian ensemble and a Cenozoic ensemble which is a superficial formation [29] [30]. These are sediments from Precambrian rocks (schists, quartzophyllades, quartzites, mica schists, gneisses, migmatites, dolomitic limestones and mylonites) which undergo physical alteration and their particles form these substrates in our sampling sites.

The rocks are interspersed in veins of white quartz, amphibolite lenses and pegmatite [30]. The two fish sampling sites in the littoral zone of Lake Tanganyika are close and present the same characteristics, for example the vegetation consists of reeds (Phragmites australis) associated with lawn and the presence of sediments predominantly made up of quartzite, quartz and pegmatite gravels with a diameter of more or less 7 to $11 \mathrm{~cm}$ with the presence of green algae growing thereon.

Natural sand and silt in small quantities were also observed along the shoreline of the sampling site. Fish sampling at Site 7 was located $20 \mathrm{~m}$ away from homes. 


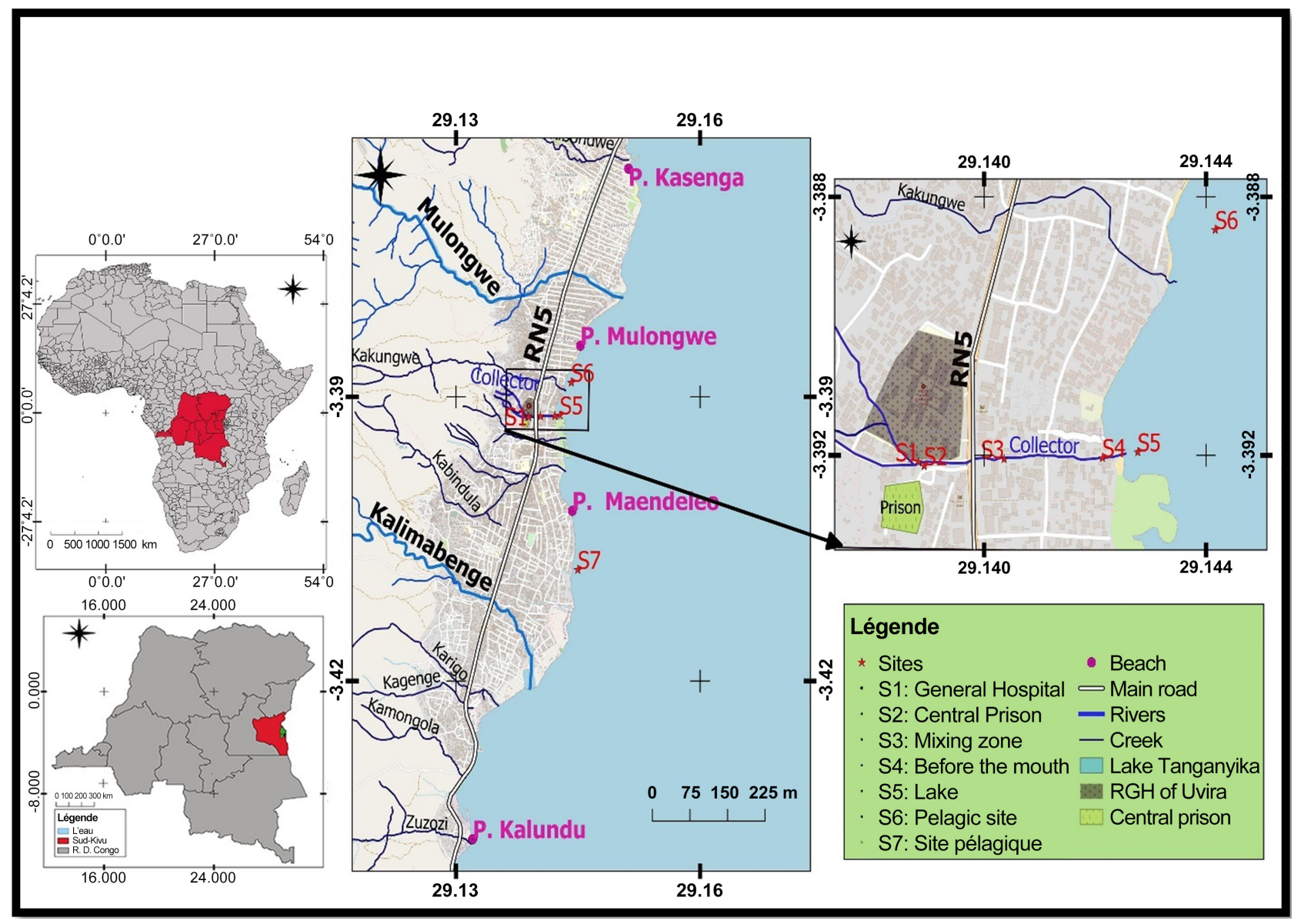

Figure 1. Location of sampling sites in green dots.

\subsection{Methodology}

The samples used for analysis of the metallic trace elements were etched with 8 $\mathrm{ml} \mathrm{HNO}_{3} 65 \%$ to ensure the perfect dissolution of the residual metal particles and $2 \mathrm{ml} \mathrm{H} \mathrm{H}_{2} \mathrm{O}_{2} 35 \%$; measured with ICP-MS: Thermo Scientific XSERIES $2 \mathrm{Qu}-$ adrupole Inductively Coupled Plasma Mass Spectrometer (ICP-MS).

Volatile organic compounds with boiling points below $200^{\circ} \mathrm{C}$, were determined using a hybrid method [31]. The method uses a Gas chromatograph$\mathrm{ic} /$ mass spectrometric procedure with sample introduction by means of purging and trapping in order to analyze several compounds. A short, narrow I.D. SPB624 column was used to shorten the analysis time to under 11 minutes. A high desorbed flow through the trap was necessary to prevent band broadening of the gaseous VOCs. This was accomplished by increasing the split ratio, thus increasing the total flow through the trap during desorption.

The method calibration data: 8260

/Haps/Method/Analyze/Headspace/ER_HSS_Tri-Bed_PPB_Quant.mth on the peak search parameters were as follows: Peak resolution: 5; Sound level multiplier: 2000; Minimum area: 50,000; Minimum width: 7; Maximum width: 70; Minimum adjustment: 0.900; Minimum purity: 0.400; Analysis time: 10. 
An inert gas was bubbled through a vessel containing the water sample. The volatile organic compounds partitioned into the gas phase were transported to a sorbent trap, where they are adsorbed. After the purge cycle, the sorbent trap was heated and the volatiles were swept into the GC column, where they were separated on the basis of their boiling points. The gas chromatograph was connected directly to a mass spectrometer which had bombarded the compounds with electrons as they sequentially exited the GC column. The resulting fragments, which have unique charge and mass characteristics for each compound, were detected by the mass detector of the spectrometer. The signal from the mass detector was used to construct a compound mass spectrum which was used to identify the compound. The detector signal intensities for the selected ions unique to each target compound were used to quantify the amount of the compound in the sample.

The toxicity tests were carried out in the aquariums of the Hydrobiology Research Center (HRC-Uvira) by bio-tests during which the fish have been exposed to a given pollutant in order to assess the concentration levels causing death.

Coastal fish of economic importance due to its consumption by the population were caught on two rocky sites and considered unpolluted in Lake Tanganyika.

This population of aquatic organisms was exposed to polluted wastewater at different concentrations of raw effluent that were successively diluted by a decimal dilution $\left(10^{0}, 10^{-1}, 10^{-9}\right)$, in aquaria for 96 hours to estimate the toxicity in order to assess the concentration levels causing toxic effects.

These tests were carried out under controlled light conditions in a well ventilated non-cumbersome aquarium room at room temperature between $24^{\circ} \mathrm{C}$ to $25^{\circ} \mathrm{C}$.

Furthermore, an air pump was used to oxygenate the water. An aquarium served as the control solution for the water samples from the lake, and in each dilution aquarium there were 20 individual fishes. The LC50 calculation method was used according to the literature [32] [33].

The least squares method consists in minimizing the sum of the squares of the deviations, in multidimensional cases between each point of the regression cloud and its projection that is parallel to the $y$-axis on the regression line.

\section{Results and Discussion}

\subsection{Inorganic Micropollutants}

The water samples used for toxicological analysis are listed in Table 2. It is worthy of note that the water from Lake Tanganyika was used as a reference and the wastewater samples from the collector diluted by 10 to $90 \%$ were considered as indicators of the toxicological level.

The highest concentrations for the different wastewater samples are underlined. 
Table 2. Results of chemical analysis on aquarium water at different dilutions, in $\mu \mathrm{g} / \mathrm{L}$.

\begin{tabular}{ccccccccccc}
\hline Conc aquarium & $\mathrm{Cr}$ & $\mathrm{Co}$ & $\mathrm{Ni}$ & $\mathrm{Cu}$ & $\mathrm{Zn}$ & $\mathrm{As}$ & $\mathrm{Sn}$ & $\mathrm{Sb}$ & $\mathrm{Hg}$ & $\mathrm{Pb}$ \\
\hline Eau du lac & 5 & 0.3 & 1.11 & 1.23 & 0.96 & 2.65 & $<0.05$ & 0.21 & 1.21 & 1.42 \\
$10 \%$ & 3.18 & 1.42 & 3.69 & 0.87 & 0.24 & 6.09 & $<0.05$ & 2.18 & $\underline{0.83}$ & $<0.05$ \\
$20 \%$ & 2.08 & 1.25 & 2.34 & 0.82 & $<0.05$ & 6.33 & $<0.05$ & 1.05 & 0.61 & $<0.05$ \\
$30 \%$ & 3.83 & 1.64 & 3.96 & 1.72 & 16 & 5.35 & 0.05 & 3.01 & 0.48 & $<0.05$ \\
$40 \%$ & 2.95 & 0.74 & 1.67 & 0.36 & $<0.05$ & 3.47 & 0.05 & 0.88 & 0.41 & $<0.05$ \\
$50 \%$ & 4.92 & 1.01 & 2.79 & 1.74 & $<0.05$ & 4.3 & $\underline{0.09}$ & 1.08 & 0.37 & $<0.05$ \\
$60 \%$ & $\underline{7.25}$ & 1.96 & 3.32 & 1.51 & 13 & 3.93 & $<0.05$ & 0.42 & 0.36 & $\underline{8.25}$ \\
$70 \%$ & 6.2 & 0.58 & 1.69 & 1.33 & 2.24 & 4.59 & $<0.05$ & $\underline{14}$ & 0.33 & $<0.05$ \\
$80 \%$ & 6.42 & 1.26 & 2.3 & 0.96 & $<0.05$ & 2.55 & $<0.05$ & 1.67 & 0.3 & 0.88 \\
$90 \%$ & 7.15 & 0.97 & 1.55 & $\underline{1.95}$ & $\underline{5.34}$ & 2.86 & $<0.05$ & 0.31 & 0.26 & $<0.05$ \\
WW & 5.55 & $\underline{2.76}$ & $\underline{4.36}$ & 0.9 & 0.47 & $\underline{7.09}$ & $<0.05$ & 1.07 & 0.22 & $<0.05$ \\
Norme OMS mg.1 & 0.05 & & 0.07 & 2 & 3 & 0.01 & 0.01 & 0.02 & 0.01 & 0.01 \\
\hline
\end{tabular}

$\%$ : dilution in percentage, Standards: [34], WW: Waste Water.

Presented in Table 2 are the guidelines for the quality of surface and drinking water, as updated in 2017, which are the benchmarks for drinking water safety

As can be seen from Table 3, the reference values are lower than those obtained from the effluents from the collector, except those for $\mathrm{Hg}$.

High concentrations of $\mathrm{Hg}$ and $\mathrm{Pb}$ were measured in the lake with values of 1.21 and $1.42 \mu \mathrm{g} / \mathrm{L}$ respectively. With regards to sampling in order to determine the toxicity of the effluent from the collector, the highest values were found to be: Pb: 8.25 ; Sb: 14; Zn: 16; Cr: 7.25; Co: 2.76; Ni: 4.36; Cu: 1.95; As: 7.09; Sn: 0.09 and $\mathrm{Hg}: 0.83 \mu \mathrm{g} / \mathrm{L}$. The variation of the different concentrations in the aquarium as listed in Table 2 does not depend on the wastewater dilution factor as these samples were taken at the same site but on sampling time, since the samples were collected on two different days. It was observed that the variation of the concentrations could be due to the different activities carried out by the users of the said collector. It was also confirmed that concentrations at the same site could be different depending on the interval and sampling time. The wastewater was found to contain inorganic micropollutants such as heavy metals, which have a negative health and environmental impact through the contamination of aquatic environments. These micropollutants originated from domestic sources such as drugs, cosmetics, detergents, pesticides, batteries, batteries and surfactants. Since hydrophobic micropollutants such as heavy micropollutants are preferentially stored in the sediments, they represent a direct risk for organisms living or feeding in the sediments as well as the higher organisms feeding on them.

These pollutants present proven or suspected harmful effects, although their concentrations in samples from Lake Tanganyika are slightly lower than those in the collector effluents. These values are higher than those reported in literature 
[22], for which $\mathrm{Cu}<0.006 \mathrm{ppm} ; \mathrm{Pb}$ is 0.007 and $\mathrm{Zn}<0.00$. In addition, our results are lower than the results [35] whose metal concentrations are slightly higher than the effluents of the wastewater treatment plants of Jaganpur and are respectively $\mathrm{Pb}, 1480$ ppb; Zn, 1159 ppb; Cd, 119 ppb; Co, 163 ppb and $\mathrm{Cr} 123$ $\mathrm{ppb}$ whereby it was also observed that the concentrations of $\mathrm{Cu}, \mathrm{Zn}$ and $\mathrm{Cd}$ were below the detection limit. The values in Table 4 describe the interaction, during 4 days, between the fish and its polluted environment in the aquariums. Some of the fish died in some aquariums, and those that survived were killed in order to determine the bioconcentration by heavy metals.

Table 3. WHO surface water quality standard.

\begin{tabular}{ccc}
\hline Element & Concentration normally found in surface water & WHO guidelines \\
\hline $\mathrm{Sb}$ & $<4 \mu \mathrm{g} / \mathrm{l}$ & $0.02 \mathrm{mg} / \mathrm{l}$ \\
$\mathrm{As}$ & - & $0.01 \mathrm{mg} / \mathrm{l}$ \\
$\mathrm{Cd}$ & $<1 \mu \mathrm{g} / \mathrm{l}$ & $0.003 \mathrm{mg} / \mathrm{l}$ \\
$\mathrm{Cr}^{+3}, \mathrm{Cr}^{+6}$ & $<2 \mu \mathrm{g} / \mathrm{l}$ & Chrome total: $0.05 \mathrm{mg} / \mathrm{l}$ \\
$\mathrm{Cu}^{+2}$ & - & $2 \mathrm{mg} / \mathrm{l}$ \\
$\mathrm{Pb}$ & - & $0.01 \mathrm{mg} / \mathrm{l}$ \\
$\mathrm{Hg}$ & $<0.5 \mu \mathrm{g} / \mathrm{l}$ & $0.01 \mathrm{mg} / \mathrm{l}$ \\
$\mathrm{Ni}$ & $<0.02 \mu \mathrm{g} / \mathrm{l}$ & $0.07 \mathrm{mg} / \mathrm{l}$ \\
$\mathrm{Zn}$ & - & $3 \mathrm{mg} / \mathrm{l}$ \\
\hline
\end{tabular}

world health organization 2017, quality guidelines for drinking water.

Table 4. Results of analysis of fish in aquariums with different concentrations, in $\mu \mathrm{g} / \mathrm{kg}$.

\begin{tabular}{ccccccccccc}
\hline Conc aquarium & $\mathrm{Cr}$ & $\mathrm{Co}$ & $\mathrm{Ni}$ & $\mathrm{Cu}$ & $\mathrm{Zn}$ & $\mathrm{As}$ & $\mathrm{Sn}$ & $\mathrm{Sb}$ & $\mathrm{Hg}$ & $\mathrm{Pb}$ \\
\hline Eau du lac & 0.21 & 0.13 & 0.21 & 0.54 & $\underline{21.13}$ & 0.18 & 0.06 & 0.01 & 0.11 & 0.49 \\
$10 \%$ & 0.15 & 0.05 & 0.28 & $\underline{4.35}$ & $\underline{21.03}$ & 0.08 & 0.01 & 0.01 & 0.08 & $\underline{0.16}$ \\
$20 \%$ & 0.37 & 0.12 & 0.25 & $\underline{0.95}$ & $\underline{15.5}$ & 0.15 & 0.01 & 0.01 & 0.01 & $\underline{0.2}$ \\
$30 \%$ & 0.27 & 0.17 & 0.17 & $\underline{0.28}$ & 9.49 & 0.22 & 0 & 0 & 0.01 & $\underline{0.11}$ \\
$40 \%$ & 0.36 & 0.39 & 0.28 & $\underline{0.81}$ & $\underline{13.6}$ & 0.2 & 0.01 & 0 & 0 & $\underline{0.2}$ \\
$50 \%$ & 0.42 & 0.16 & 0.25 & 0.57 & $\underline{14.31}$ & 0.33 & 0.02 & 0 & 0.02 & $\underline{0.23}$ \\
$60 \%$ & 0.24 & 0.09 & 0.19 & 0.48 & $\underline{14.17}$ & 0.26 & 0.02 & 0 & 0.02 & 0.28 \\
$70 \%$ & 0.13 & 0.1 & 0.29 & 0.57 & $\underline{14.89}$ & 0.21 & 0.02 & 0 & 0.02 & $\underline{0.2}$ \\
$80 \%$ & 0.24 & 0.11 & 0.62 & 0.64 & $\underline{14.54}$ & 0.24 & 0.01 & 0 & 0.03 & $\underline{0.2}$ \\
$90 \%$ & 0.1 & 0.06 & 0.09 & 0.21 & $\underline{12.47}$ & 0.19 & 0.01 & 0 & 0.03 & $\underline{0.13}$ \\
WW & 0.24 & 0.08 & 0.16 & 0.31 & $\underline{13.55}$ & 0.25 & 0 & 0 & 0.06 & $\underline{0.21}$ \\
Normes OMS mg. $\mathrm{l}^{-1}$ & & & & 30 & & 0.1 & & & 0.45 & 0.5 \\
\hline
\end{tabular}

WW: dilution with $\mathrm{x} \%$ of Waste Water. 
The underlined values in Table 4 are relatively high values of heavy metal concentrations in the fish after a 96 hour-stay in the various aquariums. For the aquariums in Table 4, these values were lower in the wastewater. The effect of bioconcentration of these metals by fish was observed. The non-underlined values in Table 4, were higher in the aquariums but not bioconcentrated by the fish. This is because of a regulatory mechanism for some heavy metals in the fish as an organism. Table 4 equally made it possible to assess the case fatality rate from wastewater in aquariums, which could be used for the determination of the LC50. It is necessary to emphasize that some heavy metals were bioconcentrated in fish while others were stable. The death of fishes was not only due to the presence of metals but also due to other organic pollutants. A wastewater toxicity test study on Oreochromis niloticus was conducted in the aquariums and the results are shown in Table 5.

After a stay of 24 hours in the aquaria of the Hydrobiology Research Center containing raw concentrated and diluted (to 50\%) wastewater, the Oreochromis niloticus species of the Cichlidae family, Order, Perciformes, captured in Nyangara Pond developed Ectofungus all over the skin.

Investigations revealed that the fish accumulated heavy metals in their ecosystems thus an improvement to existing results. Chale in 2002 [22] carried out a research on Oreochromis from Lake Tanganyika and obtained the following values: $\mathrm{Cu}$ : 5; $\mathrm{Mn}: 0.9 ; \mathrm{Zn} 28$; $\mathrm{Pb}: 2.7$ and $\mathrm{Cd} 0.2 \mu \mathrm{g} / \mathrm{g}$ in the fish sampled at Utinta. For those sampled at Kirando, he reported $\mathrm{Cu}$ 3.5; $\mathrm{Mn}: 1.6$; $\mathrm{Zn}: 58$; Pb: 6.1 and $\mathrm{Cd} 0.2 \mu \mathrm{g} / \mathrm{g}$. These results clearly demonstrate the risk of discharging wastewater directly into Lake Tanganyika, as it has harmful consequences on biodiversity.

The results in Table 6, which made it possible to assess the lethal levels of wastewater in the aquariums, were used to determine the LC50 on the basis of daily deaths. The LC50 curves are shown in Figure 2. The median lethal concentration (LC50) is a quantitative indicator of the toxicity of a substance. This indicator measures the dose of a substance causing the death of $50 \%$ of a given animal population under specific experimental conditions, usually during acute exposure.

With regards to the curve presented in Figure 2, it was noticed that all the twenty fishes studied were dead on the first day in the raw sewage tank $(100 \%$ concentrated). After 24 hours, the deaths were observed in the aquariums diluted to $10^{-1}$ and $10^{-2}$. There were no deaths in aquariums diluted from $10^{-9}$ to $10^{-3}$ wastewater during the 4 days. However, several observations relating to the behavior of fish have been reported, including the appearance of sores infected with cottony tufts or fungi all over the body. These pollutants damaged the fins of the fish and the swimming movement was significantly reduced. There was also exophthalmos and the presence of trematode in the aquarium containing the concentrated wastewater. The LC50 of the acute toxicity test carried out over 4 days corresponded to $0.0055 \mathrm{ml} / \mathrm{ml}$. The LC100 was observed in raw wastewater, after a few hours which explains why the effluent is very toxic. 
The values underlined in Table 6, are the bioconcentrates by the fish during 4 days in the wastewater of the aquariums. $\mathrm{Zn}$ and $\mathrm{Pb}$ are bioconcentrated while with $\mathrm{Cu}$, there is more control from the aquarium by 50 to $100 \%$. The fishes had also succeeded to stabilize metal ions such as $\mathrm{Cr}, \mathrm{Co}, \mathrm{Ni}, \mathrm{As}, \mathrm{Sn}, \mathrm{Sb}$ and $\mathrm{Hg}$, found in the control aquarium of Lake Tanganyika at $100 \%$. Zinc is an essential trace element for human health. It is important for the physiological functions of

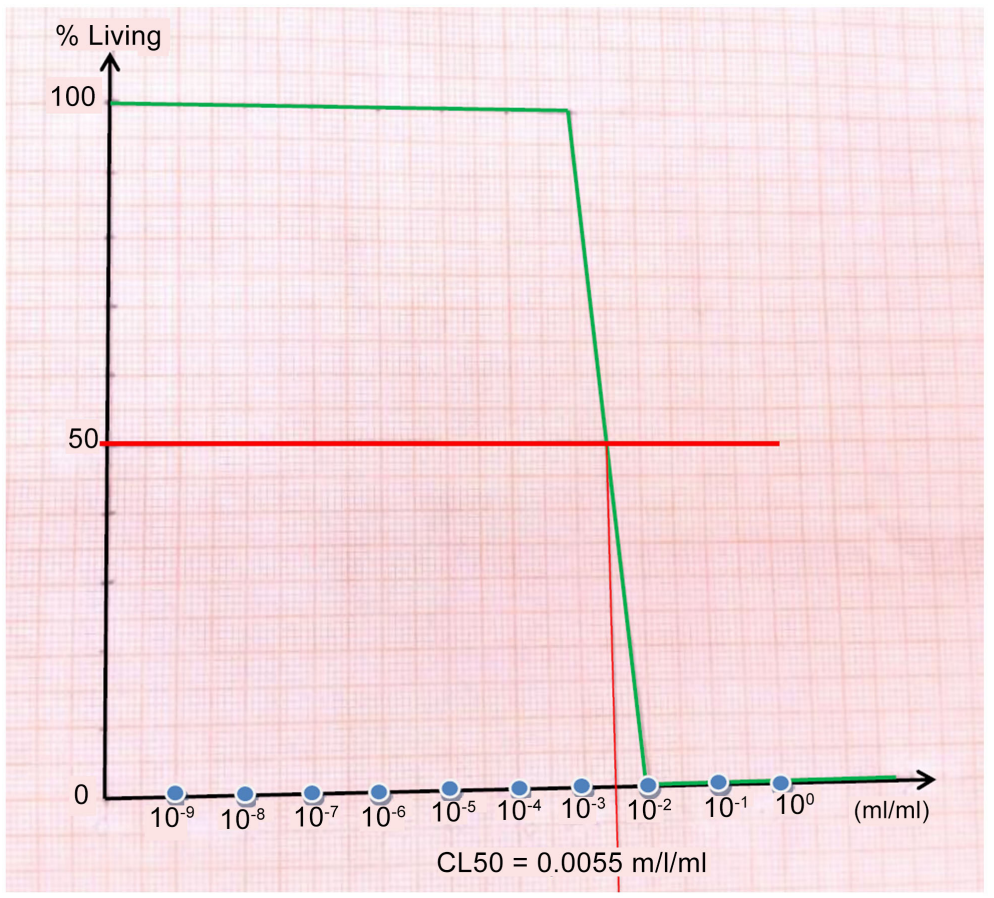

Figure 2. Determination of LC50.

Table 5. Description of acute toxicity test on Oreochromis niloticus in aquariums expressed in $\mathrm{mg} \cdot \mathrm{kg}^{-1}$.

\begin{tabular}{lcc}
\hline \multicolumn{2}{c}{ Species } \\
\hline \multicolumn{3}{c}{ Oreochromis niloticus } \\
\hline $\mathrm{ETM}$ & $\mathrm{X} \pm \mathrm{SD}$ & Waste water diluted at $50 \%$ \\
$\mathrm{Al}$ & $707.25 \pm 419.3$ & $\mathrm{X} \pm \mathrm{SD}$ \\
$\mathrm{Cr}$ & $1.5 \pm 0.57$ & $30.33 \pm 15.69$ \\
$\mathrm{Mn}$ & $49.5 \pm 17.59$ & $0.33 \pm 0.57$ \\
$\mathrm{Ni}$ & $2.5 \pm 0.57$ & $28.33 \pm 19.55$ \\
$\mathrm{Cu}$ & $3.7 \pm 0.5$ & $2 \pm 1$ \\
$\mathrm{Zn}$ & $53.75 \pm 20.48$ & $2.66 \pm 0.57$ \\
$\mathrm{Pd}$ & $0.34 \pm 0.17$ & $50 \pm 19$ \\
$\mathrm{Ag}$ & $0.062 \pm 0.060$ & $0.033 \pm 0.02$ \\
$\mathrm{Cd}$ & $0.022 \pm 0.026$ & $0.013 \pm 0.0057$ \\
$\mathrm{~Pb}$ & $0.76 \pm 0.16$ & $0.02 \pm 0.025$ \\
\hline
\end{tabular}


Table 6. Lethal dose (LC50).

\begin{tabular}{|c|c|c|c|c|c|c|}
\hline \multirow{2}{*}{ Concentration } & \multicolumn{4}{|c|}{ \# Deaths } & \multirow{2}{*}{ \# Living } & \multirow{2}{*}{ \% Living } \\
\hline & $1^{\text {st }}$ day & $2^{\text {nd }}$ day & $3^{\text {rd }}$ day & $4^{\text {th }}$ & & \\
\hline $10^{0}$ & 20 & - & 0 & 0 & 0 & 0 \\
\hline $10^{-1}$ & 18 & 2 & 0 & 0 & 0 & 0 \\
\hline $10^{-2}$ & 5 & 15 & 0 & 0 & 0 & 0 \\
\hline $10^{-3}$ & 0 & 0 & 0 & 0 & 20 & 100 \\
\hline $10^{-4}$ & 0 & 0 & 0 & 0 & 20 & 100 \\
\hline $10^{-5}$ & 0 & 0 & 0 & 0 & 20 & 100 \\
\hline $10^{-6}$ & 0 & 0 & 0 & 0 & 20 & 100 \\
\hline $10^{-7}$ & 0 & 0 & 0 & 0 & 20 & 100 \\
\hline $10^{-8}$ & 0 & 0 & 0 & 0 & 20 & 100 \\
\hline $10^{-9}$ & 0 & 0 & 0 & 0 & 20 & 100 \\
\hline Witnesses & 0 & 0 & 0 & 0 & 20 & 100 \\
\hline
\end{tabular}

living tissue and regulates many biochemical processes. However, excess zinc in the human body can cause prominent health problems such as stomach cramps, irritation, vomiting, nausea and anemia [36]. Copper plays an essential role in animal metabolism but its excessive ingestion leads to serious toxicological problems such as vomiting, cramps, convulsions and even death [37]. The direct effects of these metals in fish are not yet well understood. In the present study, the toxicological effects of the stable metallic trace elements $\mathrm{Hg}$ and $\mathrm{Pb}$ were investigated on samples obtained from 5 different sites and the results are presented in Table 7.

According to the values in Table 7, the concentrations of $\mathrm{Pb}$ and $\mathrm{Hg}$ vary from one site to another. Evidently, the concentrations are very high at the 4 sampling sites of the collector. It is noted that these concentrations were also high in Lake Tanganyika. Among the sites investigated, the statistical difference was significant only at the central prison and household sites, with $\mathrm{p}=0.05$. Sources of Lead in the environment include foundries, metallurgy industries, coal combustion, waste incineration, batteries, electrical devices, biocides, plastics, boxes of cans contaminated with old lead pipes and certain containers glazed with lead or lead-tin alloy (false "tins") [38] [39].

\subsection{Organic Micropollutants}

These compounds are usually present in concentrations of the order of ppb $(=\mu \mathrm{g} / \mathrm{L})$. Table 8 presents the concentrations $(\mathrm{ppb})$ of volatile organic compounds in the wastewater obtained from the General Reference Hospital of Uvira, the mixing of the GRH, the Central Prison and the households which are connected to the collector and the coast of Lake Tanganyika at the outlet of the collector. 
Table 7. Monitoring of hazardous metallic trace elements in the collector.

\begin{tabular}{cccccccc}
\hline & \multicolumn{3}{c}{$\mathrm{Hg}(\mathrm{ppb})$} & \multicolumn{3}{c}{$\mathrm{Pb}(\mathrm{ppm})$} & p-value \\
\cline { 2 - 7 } & $\mathrm{X} \pm \mathrm{SD}$ & Min & Max & $\mathrm{X} \pm \mathrm{SD}$ & Min & Max & \\
\hline $\mathrm{CP}$ & $17.07 \pm 0.82$ & 16.032 & 18.007 & $0.41 \pm 0.16$ & 0.245 & 0.612 & $\mathrm{PC} \& \mathrm{GH}=0.24$ \\
$\mathrm{GH}$ & $13.57 \pm 4.90$ & 6.726 & 18.367 & $0.51 \pm 0.19$ & 0.379 & 0.67 & $\mathrm{PC} \& \mathrm{GH}=0.05$ \\
$\mathrm{HW}$ & $15.3 \pm 1.36$ & 13.64 & 18.007 & $0.37 \pm 0.3$ & 0.009 & 0.6 & $\mathrm{HW} \& \mathrm{Lac}=0.38$ \\
$\mathrm{LT}$ & $10.37 \pm 4.77$ & 6.801 & 17.415 & $0.3 \pm 0.2$ & 0.188 & 0.61 & PC \& LT $=0.08$ \\
\hline
\end{tabular}

${ }^{*} \mathrm{p}<0.001$ : Highly significant, ${ }^{* *} \mathrm{p}<0.01$ : very significant and ${ }^{* * *} \mathrm{p}<0.05$ : significant. CP: Central prison. GH: General hospital. HW: household waste. LT: Lake Tanganyika.

Table 8. Concentrations in ppb of organic compounds in wastewater and lake Tangayika.

\begin{tabular}{ccccc}
\hline Compound & GRH & GRH, CP, HW & LT & Standard \\
\hline Benzene & $<0.05$ & $<0.05$ & $<0.05$ & $10^{-4}$ \\
Toluene & 0.53 & 0.678 & 0.341 & $10^{-4}$ \\
Ethylbenzene & 0.065 & 0.071 & $<0.05$ & $10^{-4}$ \\
m-Xylene/p-Xylene & 0.067 & 0.051 & 0.054 & $2 \times 10^{-4}$ \\
o-Xylene & 0.1 & $<0.05$ & $<0.05$ & $2 \times 10^{-4}$ \\
Chloroform & 0.498 & 0.983 & $<0.05$ & $10^{-5}$ \\
Bromodichloromethane & $<0.05$ & $<0.05$ & $<0.05$ & - \\
1,1-Dichloroethane & $<0.05$ & $<0.05$ & $<0.05$ & $6.10^{-6}$ \\
\hline
\end{tabular}

GRH: General Reference Hospital, CP: Central Prison, HW: Households waste, ppb: parts per billion.

Generally, wastewater and hospital effluent contain several organic micropollutants such as: hydrocarbons, polychlorinated biphenyls (PCB), polybrominated biphenyls (PBB), polychlorinated dibenzodioxins (PCDD), polychlorinated dibenzofurans (PCDF), detergents (or surfactants), phthalate esters, various drug substances, but these were not detected in the present study. Perhaps high performance laboratory equipment was required for their detection. Nevertheless, toluene, ethylbenzene, m-xylene/p-xylene, o-xylene and chloroform were detected at concentrations higher than the recommended standard. Benzene, bromodichloroethane, and 1,1-dichloroethane were present in the samples but in concentrations less than $0.05 \mathrm{ppb}$, which is the limit of detection for ICP-MS. The samples collected at the mixing point of the GRH, CP and $\mathrm{H}$ effluents before leaving Lake Tanganyika were found to contain: toluene, ethylbenzene, $\mathrm{m}$-xylene/p-xylene and chloroform at concentrations above the standard but with no o-xylene.

According to our results, the hospital effluent was found to contain toluene, ethylbenzene, $\mathrm{m}$-xylene/p-xylene, o-xylene and chloroform in higher concentrations than the standard. Moreover, Benzene, bromodichloroethane and 1,1-dichloroethane were detected in these samples, but in concentrations less than 0.05 ppb, which is the ICP-MS detection limit. It was observed that the concentrations of toluene, ethylbenzene and chloroform increased during mixing, which 
explains the contribution of the Central Prison, which has a dispensary. In Lake Tanganyika, a high concentration of toluene and $\mathrm{m}$-xylene/p-xylene was observed, compared to the standard, which presents a great danger to the biodiversity and the surrounding population that depends on this water for domestic purposes.

Very few studies on this topic have been published in literature. The research works carried out on the two rivers Rhine and IJsselmeer in Europe [40] [41] [42], yielded lower values than those reported in this study, in particular: 0.2 $\mu \mathrm{g} / \mathrm{L}$ toluene, $<0.1 \mu \mathrm{g} / \mathrm{L}$ bromodichloroethane and $<0.1 \mu \mathrm{g} / \mathrm{L}$ chloroform in the IJsselmeer river water and $<0.1 \mu \mathrm{g} / \mathrm{L}$ toluene, $<0.1 \mu \mathrm{g} / \mathrm{L}$ bromodichloethane and $0.2 \mu \mathrm{g} / \mathrm{L}$ chloroform for the Rhine river water. Previous studies showed that the micropollutants found in urban water (waste and rainwater) come from domestic, artisanal, industrial activities, road traffic, rain runoff water and road cleaning, maintenance practices of urban spaces (green spaces, facades, etc.) [43].

Some compounds have easily identifiable sources such as parabens or pharmaceutical residues which largely come from domestic uses and are restricted to wastewater or polycyclic aromatic hydrocarbons which are mainly produced by automobile traffic and are abundantly present in rainwater. On the contrary, micropollutants such as alkylphenols, have many origins linked to the multiplicity of their uses [5]. Other micropollutants come from domestic cleaning products like disinfectants and body care products. [44] [45]. The probable sources of micropollutants identified in this study in the city of Uvira are degradation of wastes from the processing of agro-food products, used car parts such as lead accumulators, household waste dumped in the environment, effluents of pharmaceutical residues and phytosanitary products into the environment.

\section{Conclusions}

This study had as main aim to determine the ecotoxicological risk of urban waste from the city of Uvira discharged into Lake Tanganyika on the northwest coast of the Democratic Republic of Congo. The study showed the presence of inorganic micropollutants at high concentration compared to the standards such as: $\mathrm{Cr}, \mathrm{Co}, \mathrm{Ni}, \mathrm{Cu}, \mathrm{Zn}, \mathrm{As}, \mathrm{Sb}, \mathrm{Hg}$ and $\mathrm{Pb}$, while $\mathrm{Sn}$ was found to be too low and negligible.

The presence of $\mathrm{Pb}$ and $\mathrm{Hg}$ at significant concentrations was observed at all sampling sites including the shore of Lake Tanganyika. Some organic micropollutants were identified in high concentrations except those in the samples obtained from the General Hospital of Uviral which is attributable to pharmaceutical residues.

The acute ecotoxicological experiment carried out on aquariums at the Center for Research in Hydrobiology showed that about $50 \%$ of the fish population in the investigated region is likely to die at the concentration of $0.0055 \mathrm{ml} / \mathrm{ml}$ of water which confirms that the wastewater from the above-mentioned sources is toxic.

It is important to put in place and to strictly respect some regulations that 
would guarantee the purity of Lake Tanganyika. Regular monitoring of the pollution level of the water is also recommended.

Measures to prevent the sale of products containing extremely toxic and poorly biodegradable compounds would be an asset. The application of the membrane process for the removal of non-biodegradable compounds or elements contained in solid-liquid and liquid-liquid, could be a perfect solution to the pollution problem of Lake Tanganyika. These measures, if implemented, are very likely to improve upon the quality of water from Lake Tanganyika.

\section{Acknowledgements}

The authors acknowledge the support received from the Chemistry Engineering Department at KU Leuven, the Chemistry laboratory at the Hydrobiology Research Center, and the UERHA environmental analysis laboratory at the Higher Pedagogical Institute of Bukavu.

\section{Conflicts of Interest}

The authors declare no conflicts of interest regarding the publication of this paper.

\section{References}

[1] Organisation Mondiale de la Santé (2017) Directives de qualité de l'eau de boisson: Quatrième Édition intégrant le premier additif.

[2] Osvaldo, E., Sala, F., Chapin, S., Armesto, J.J., Berlow, E., Bloomfield, J., Dirzo, R., Huber-Sanwald, E., Huenneke, L.F., Jackson, R.B., Kinzig, A., Leemans, R., Lodge, D.M., Mooney, H.A., Oesterheld, M., Poff, N.L., Sykes, M.T., Walker, B.H., Walker, M. and Wall, D.H. (2000) Global Biodiversity Scenarios for the Year 2100. Science, 287, 1770-1774. http://www.jstor.org/stable/3074591 https://doi.org/10.1126/science.287.5459.1770

[3] Dudgeon, D., et al. (2006) Freshwater Biodiversity: Importance, Threats, Status and Conservation Challenges. Biological Reviews, 81, 163-182. https://doi.org/10.1017/S1464793105006950

[4] Coumoul, X., Massicot, F. and Pairon, J.C. (2017) Toxicologie. https://www.dunod.com

[5] Briand, C., Bressy, A., Ghassan, C., Deroubaix, J. and Deshayes, S. (2018) Que saiton des micropolluants dans les eaux urbaines?

[6] Beal, C., Gardner, E., Kirchhof, G. and Menzies, N. (2006) Long-Term Flow Rates and Biomat Zone Hydrology in Soil Columns Receiving Septic Tank Effluent. Water Research, 40, 2327-2338. https://doi.org/10.1016/j.watres.2006.04.018

[7] Maxime, P., Nicolas, S., Marnik, V. and Gerin, P.A. (2020) EPUSOL-Mission de Guidance sur le Traitement approprié et la capacité épuratoire des sols. 665 p. http://hdl.handle.net/2078.1/235795

[8] Hua, M., Zhang, S., Pan, B., Zhang, W., Lv, L. and Zhang, Q. (2012) Heavy Metal Removal from Water/Wastewater by Nanosized Metal Oxides: A Review. Journal of Hazardous Materials, 211-212, 317-331. https://doi.org/10.1016/j.jhazmat.2011.10.016

[9] Ihsanullah, Abbas, A., Al-Amer, A.M., Laoui, T., Al-Marri, M.J., Nasser, M.S., Khrai- 
sheh, M. and Atieh, M.A. (2016) Heavy Metal Removal from Aqueous Solution by Advanced Carbon Nanotubes: Critical Review of Adsorption Applications. Separation and Purification Technology, 157, 141-161. https://doi.org/10.1016/j.seppur.2015.11.039

[10] Fu, F. and Wang, Q. (2011) Removal of Heavy Metal Ions from Wastewaters: A Review. Journal of Environmental Management, 92, 407-418.

https://www.journals.elsevier.com/journal-of-environmental-management https://doi.org/10.1016/j.jenvman.2010.11.011

[11] Zhao, M., Xu, Y., Zhang, C., Rong, H. and Zeng, G. (2016) New Trends in Removing Heavy Metals from Wastewater. Applied Microbiology and Biotechnology, 100, 6509-6518. https://doi.org/10.1007/s00253-016-7646-X

[12] Li, Y., Xu, Z., Li, S., Zhang, J. and Yang, X. (2017) Molecular Simulation of Reverse Osmosis for Heavy Metal Ions Using Functionalized Nanoporous Graphenes. Computational Materials Science, 139, 65-74.

https://www.journals.elsevier.com/computational-materials-science https://doi.org/10.1016/j.commatsci.2017.07.032

[13] Ahmet,A. and Yigit, S. (2005) Assessment of Heavy Metal Concentrations in the Food Web of Lake Beysehir, Turkey. Chemosphere, 60,552-556.

https://doi.org/10.1016/j.chemosphere.2005.01.009

[14] Chen, C.Y., Stemberger, R.S., Klaue, B., Blum, J.D., Pickhardt, C. and Folt, C.L. (2000) Accumulation of Heavy Metals in Food Web Components across a Gradient of Lakes. Limnology and Oceanography, 45, 1525-1536. https://doi.org/10.4319/lo.2000.45.7.1525

[15] Kalay, M. and Canli, M. (2000) Elimination of Essential (Cu, Zn) and Non-Essential $(\mathrm{Cd}, \mathrm{Pb})$ Metals from Tissue of a Freshwater Fish Tilapia zilli. Turkish Journal of Zoology, 24, 429-436.

[16] Gouzy, A. and Ducos, G. (2008) La connaissance des éléments traces métalliques: Un défi pour la gestion de l'environnement.

[17] Musibono, D.E. and Day, J.A. (2000) Active Uptake of Aluminium, Copper and Manganese by the Freshwater Amphipod Paramelita Nigroculus in Acidic Waters. Hydrobiologia, 437, 213-219.

[18] Fernand, G. (1975) Le 400ème chat: Ou Les pollués de Minamata. Robert Laffont, Paris.

[19] Lévy, C. (2008) Maladies industrielles et renouveau syndical au Japon. In: EbisuÉtudes Japonaises, Maison Franco-Japonaise, Tokyo, 181-184. https://www.persee.fr/doc/ebisu 1340-3656 2008 num $39 \quad 1 \quad 1504$

[20] Le Henry, J. (2019) PwC-Strategy and Industrialisation en Afrique: Réaliser durablement le potentiel du Continent. https://www.jeuneafrique.com/744907/economie/jonathan-le-henry-pwc-les-politiq ues-de-developpement-en-silo-ont-freine-lindustrialisation-de-lafrique/

[21] Rashed, M.N. (2001) Monitoring of Environmental Heavy Metals in Fish from Nasser Lake. Environment International, 27, 27-33. https://doi.org/10.1016/S0160-4120(01)00050-2

[22] Chale, F.M.M. (2002) Trace Metal Concentrations in Water, Sediments and Fish Tissue from Lake Tanganyika. Science of the Total Environment, 299, 115-121. https://doi.org/10.1016/S0048-9697(02)00252-8

[23] Okwonko, J.O. and Mothiba, M. (2005) Physico-Chemical Characteristics and Pollution Levels of Heavy Metals in the Rivers in Thohoyandou, South Africa. Journal of Hydrology, 308, 122-127. https://doi.org/10.1016/j.jhydrol.2004.10.025 
[24] Asony,e C.C., Okoline, N.P., Okenwa, E.E. and Iwuanyanwu, U.G. (2007) Some Physicochemic Characteristics and Heavy Metal Profiles of Nigerian Rivers, Streams and Waterways. African Journal of Biotechnology, 6, 617-624.

[25] Nsimanda, C., Dieudonné Musibono, E.D., Norbert Basosila, L. and Bienvenu Wanga, B.M. (2015) Contribution to the Ecotocological Study on Cadmium and in Lead Contamination of Distichodus fasciolatus, Mormyrops anguilloides and Schilbe mistus (Pisces) from the Pool Malebo at MALUKU Upstream Kinshasa City (Congo River, DR Congo). International Journal of Innovation and Applied Studies, 10, 166-175. https://citeseerx.ist.psu.edu/viewdoc/download?doi=10.1.1.687.2794\&rep=rep1\&typ $\underline{\mathrm{e}=\mathrm{pdf}}$

[26] Lumami, K., Muyisa, S. and Jung, G.C. (2016) Contribution à l'état des lieux de déchets solides ménagers dans la ville D’Uvira, Sud-Kivu, République Démocratique du Congo. International Journal of Biological and Chemical Sciences, 10, 1413-1421. https://doi.org/10.4314/ijbcs.v10i3.39

[27] West, K. (2001) Résultats et constats tires de l'initiative de conservation du PNUD/ GEF (raf/92/g32) qui a eu lieu au Burundi, en République Démocratique du Congo, en Tanzanie et en Zambie.

https://citeseerx.ist.psu.edu/viewdoc/download?doi=10.1.1.687.2794\&rep=rep1\&typ $\underline{\mathrm{e}=\mathrm{pdf}}$

[28] Lumami, K., Ndikumana, T., Musibono, D.D., Alconero, L.P., Njoyim, E.B.T., Tarimo, I. and Van der Bruggen, B. (2020) Qualitative and Quantitative Analysis of the Pollutant Load of Effluents Discharged Northwestern of Lake Tanganyika, in the Democratic Republic of Congo. African Journal of Environmental Science and Technology, 14, 361-373. http://www.academicjournals.org/AJEST https://doi.org/10.5897/AJEST2020.2903

[29] Ilunga (2006) Etude des sites majeurs d'érosion à Uvira (R.D. Congo). Geo-Eco-Trop, $30,1-12$.

[30] Weis, G. (1959) Les pays d’Uvira: Étude de géographie régionale sur la bordure occidentale du lac Tanganika. Académie royale des sciences coloniales, Bruxelles.

[31] SAIC (1992) This Protocol Was Established by This Company to Measure Organic Micropollutants. An Employee Company Science Applications International Corporation.

[32] Finney, D.J. (1971) Probit Analysis. 3rd Edition, University Press, Cambridge.

[33] Branko M.A. and Akram M.R. (2014) Comparaison des méthodes de Finney et MillerTainter pour le calcul des valeurs DL50. Worlde Sciences Journal, 32, 2167-2170.

[34] ESDAC (2007) Derivation Methods of Soil Screening Values in Europe: A Review and Evaluation of National Procedures towards Harmonization.

[35] Maurya, C. and Srivastava, J.N. (2019) Current Seasonal Variations in Physicochemical and Heavy Metals Parameters of Sewage Treatment Plant Effluent and Suitability for Irrigation. Journal of Water Resource and Protection, 11, 852-865. https://doi.org/10.4236/jwarp.2019.117052

[36] Oyaro, N., Juddy, O., Murago, E.N.M. and Gitonga, E. (2007) The Contents of Pb, $\mathrm{Cu}, \mathrm{Zn}$ and $\mathrm{Cd}$ in Meat in Nairobi, Kenya. International Journal of Agriculture, Environment and Food Sciences, 5, 119-121.

[37] Paulino, A.T., Minasse, F.A.S., Guilherme, M.R., Reis, A.V., Muniz, E.C. and Nozaki, J. (2006) Novel Adsorbent Based on Silkworm Chrysalides for Removal of Heavy Metals from Wastewaters. Journal of Colloid and Interface Science, 301, 479-487. https://doi.org/10.1016/j.jcis.2006.05.032 
[38] Sindy, G.M. (2006) Les métaux (Cd, Cu, Pb et $\mathrm{Zn}$ ) dans la Production des Microalgues sur différents milieux de culture : Biodisponibilité, Bioaccumulation et Impact Physiologique. Thèse de Doctorat en Biologie Marine. Université de Nantes, Nantes.

[39] Lamprea, K. (2009) Caractérisation et origine des métaux traces, hydrocarbures aromatiques Polycycliques et pesticides transportés par les retombées atmosphériques et les eaux de Ruissellement dans les bassins versants séparatifs péri-urbains.

[40] Hofman, J.A.M.H., Beerendonk, E.F., Folmer, H.C. and Kruithof, J.C. (1997) Removal of Pesticides and Other Micropollutants with Cellulose-Acetate, Polyamide and Ultra-Low Pressure Reverse Osmosis Membranes, Desalination, 113, 209-214. https://doi.org/10.1016/S0011-9164(97)00131-8

[41] Extoxnet (2002) National Pesticide Information Center. http://www.ace.orst.edu/

[42] Van der Bruggen, B. and Vandecasteele, C. (2002) Removal of Pollutants from Surface Water and Groundwater by Nanofiltration: Overview of Possible Applications in the Drinking Water Industry. Environmental Pollution, 122, 435-445.

https://www.journals.elsevier.com/environmental-pollution https://doi.org/10.1016/S0269-7491(02)00308-1

[43] Petrucci, G., Gromaire, M.C. and Chebbo, G. (2014) Analyse des sources primaires diffuses de Métaux et HAP et modélisation des flux annuels émis dans les eaux de ruissellement, ANR INOGEV: Innovations pour une Gestion durable de l'Eau en Ville, Tâche 3, Rapport final de sous-tâche.

[44] Deshayes, S. (2015) Identification des sources de phtalates et d'alkylphénols (polluants Émergents) en milieu urbain et compréhension des processus d'élimination. Thèse de Doctorat, LEESU et LCPC, Université Paris-Est, Paris.

[45] Zedek, S. (2016) Dynamique de polluants émergents (parabènes, triclosan et triclocarban) dans le continuum eaux grises-milieu récepteur. Thèse de Doctorat, LEESU, Université Paris-Est, Paris. 